\title{
Linseed-based diets for sheep. 2. Performance and chemical composition of meat and liver ${ }^{*}$
}

\author{
F. Borowiec' ${ }^{1}$, P. Micek ${ }^{1,3}$, M. Marciński ${ }^{1}$, J. Barteczko' and T. Zając ${ }^{2}$ \\ Agricultural University of Crakow; \\ 'Department of Animal Nutrition, \\ Department of Plant Production \\ Al. Mickiewicza 24/28, 30-059 Kraków, Poland
}

\begin{abstract}
The effects of dietary linseed cultivars, traditional (Opal, Omega) or the new Linola cultivar with an increased content of linoleic acid, on the performance and chemical composition of lamb meat and liver were investigated. The animals were fed meadow hay and concentrate. The control group received no linseed in concentrate, whereas the experimental groups received $10 \%$ crushed linseed of different cultivars. There was no significant effect of linseed, irrespective of cultivar, on daily weight gains of the lambs, feed conversion, dressing percentage and chemical composition of leg muscle and liver. However, significant $(\mathrm{P}<0.05)$ changes were shown in the fatty acid profile of meat and liver.
\end{abstract}

KEY WORDS: linseed, lambs, meat, liver, chemical composition

\section{INTRODUCTION}

Fat in linseed is characterized by a high content of unsaturated fatty acids, which may adversely affect microorganism growth and nutrient utilization in the rumen (Jenkins, 1993). Market varieties of linseed vary in their fatty acid composition, which may positively affect the performance of lambs and the dietary value of their meat. Traditional cultivars have a high content of $\mathrm{C}_{18: 3}$, while the new cultivar Linola is higher in $\mathrm{C}_{18: 2}$ and lower in $\mathrm{C}_{18: 3}$ acid (Borowiec et al., 2001). The aim of the present study was to determine the effects of dietary linseed cultivars (traditional ones and Linola) on performance as well as on the chemical composition of meat and liver of lambs.

\footnotetext{
* Supported by the State Committee for Scicntific Rescarch, Grant No. 6 P06Z 01321

'Corresponding author: e-mail: rzmicek(âcyf.kr.edu.pl
} 


\section{MATERIAL AND METHODS}

The lambs were fattened for 55 days from about 20 to $31 \mathrm{~kg}$ body weight. The animals were assigned to 4 groups of 10 animals and were fed meadow hay (0.5$0.7 \mathrm{~kg} / \mathrm{head})$ and concentrate $(0.4-0.65 \mathrm{~kg} / \mathrm{head})$. The control group $\left(\mathrm{I}_{\mathrm{K}}\right)$ received no supplemental linseed in concentrate, whereas groups $\mathrm{II}_{\mathrm{ON}}, \mathrm{II}_{\mathrm{OM}}$ and $\mathrm{IV}_{\mathrm{T}}$ received $10 \%$ crushed linseed of cultivars Opal, Omega, or Linola ${ }^{\mathrm{MM} \% \mathrm{~T}}$, respectively. All diets were isonitrogenous and only slightly differed in energy value. At the end of fattening, 4 animals from each group were slaughtered and representative samples of leg muscle and liver were taken for analyses. The chemical composition of feeds, meat and liver was determined according to AOAC (1995) methods. The fatty acid profile was analysed by gas chromatography (Varian Star 3400 CX; detector FID). The data were subjected to one-way analysis of variance using the GLM procedure of SAS (1995). The individual means were compared by the Scheffe test (SAS, 1995).

\section{RESULTS}

Compared with the control diet, traditional linseed cultivars (Opal and Omega) caused an increase in the content of $\mathrm{C}_{18: 3}$, while the Linola cultivar supplement increased the content of $\mathrm{C}_{1 \times: 2}$ in the fatty acid profile of the diets.

There was no statistically significant effect of feeding linsecd concentrate on daily weight gains of the lambs, feed conversion or dressing percentage (Table 1)

TABLE 1

Performance of lambs

\begin{tabular}{|c|c|c|c|c|c|c|}
\hline \multirow{2}{*}{ Item } & \multicolumn{4}{|c|}{ Group } & \multirow{2}{*}{$P$} & \multirow{2}{*}{ SEM } \\
\hline & $I_{k}$ & $\mathrm{II}_{\mathrm{OP}}$ & $\mathrm{III}_{\text {OM }}$ & $\mathrm{IV}_{\mathrm{LI}}$ & & \\
\hline Daily weight gain, $\mathrm{g}$ & 178.9 & 174.2 & 168.0 & 172.0 & 0.9828 & 9.34 \\
\hline \multicolumn{7}{|c|}{ Energy and protein conversion, per kg of gain } \\
\hline UFV & 4.97 & 5.22 & 5.40 & 5.29 & - & - \\
\hline PDIN, g & 498.6 & 512.6 & 532.7 & 522.7 & - & - \\
\hline PDIF, $g$ & 531.4 & 552.1 & 552.6 & 539.8 & - & - \\
\hline Hot carcass yicld, $\%$ & 42.9 & 43.8 & 42.5 & 44.1 & 0.5668 & 0.53 \\
\hline Cold carcass yield, $\%$ & 40.9 & 42.0 & 40.8 & 42.2 & 0.6587 & 0.54 \\
\hline
\end{tabular}

as well as on the chemical composition of meat and liver (Table 2). In these tissues, the cholesterol content was increased in each experimental group $(\mathrm{P}>0.05)$. Moreover, significant changes were noted in the fatty acid profile of meat and liver. There was an increase in the sum of unsaturated fatty acids (mainly $\mathrm{C}_{18: 1}$ and $\mathrm{C}_{18: 3}$ in groups $\mathrm{II}_{O \mathrm{P}}$ and $\mathrm{III}_{\mathrm{OM}}$, and $\mathrm{C}_{18: 2}$ in group $\mathrm{IV}_{1,1}$ as well as CLA in all experimental 
groups) which was accompanicd by a decrease in the saturated fatty acid content (mainly palmitic acid in meat and stearic acid in liver).

TABLE 2

Chemical composition and fatty acid profilc of leg muscle, $\%$

\begin{tabular}{|c|c|c|c|c|c|c|}
\hline \multirow{2}{*}{ Item } & \multicolumn{4}{|c|}{ Group } & \multirow[t]{2}{*}{$P$} & \multirow[t]{2}{*}{$\mathrm{S} \Gamma$} \\
\hline & $I_{k}$ & $1 I^{O T}$ & $\mathrm{III}_{\mathrm{OM}}$ & $I_{11}$ & & \\
\hline Dry matter, \% & 22.66 & 23.11 & 23.55 & 24.27 & 0.4860 & 0.36 \\
\hline Crude ash, $\%$ & 1.16 & 1.20 & 1.15 & 1.18 & 0.4437 & 0.01 \\
\hline Crude protein, $\%$ & 20.35 & 20.58 & 20.24 & 20.15 & 0.9570 & 0.26 \\
\hline Ether extract. \% & 2.14 & 2.01 & 2.40 & 2.72 & 0.6747 & 0.21 \\
\hline Total cholcstcrol. mg $\%$ & 92.10 & 103.75 & 102.48 & 105.63 & 0.5059 & 3.28 \\
\hline \multicolumn{7}{|l|}{ Fatty acids } \\
\hline $\mathrm{C}_{14: 0}$ & 2.02 & 1.97 & 1.94 & 2.07 & 0.9807 & 0.11 \\
\hline $\mathrm{C}_{: 6: 0}$ & $23.11^{\mathrm{a}}$ & 21.37 & $21.09^{\mathrm{ab}}$ & $20.51^{l \prime}$ & 0.0374 & 0.36 \\
\hline $\mathrm{C}_{: 6::}$ & 0.93 & 1.01 & 1.28 & 0.91 & 0.3355 & 0.08 \\
\hline $\mathrm{C}_{18: 0}$ & 21.11 & 21.40 & 19.78 & 21.94 & 0.3281 & 0.42 \\
\hline $\mathrm{C}_{18: 1}$ & $35.55^{\mathrm{B}}$ & $38.38^{\mathrm{A}}$ & $39.49^{\wedge}$ & $35.47^{13}$ & 0.0001 & 0.49 \\
\hline $\mathrm{C}_{18: 2}$ & 11.29 & 10.02 & 10.35 & 12.66 & 0.2355 & 0.49 \\
\hline $\mathrm{C}_{18: 3}$ & $1.02^{\mathrm{b}}$ & $1.85^{\circ}$ & $2.23^{a}$ & $1.08^{\mathrm{b}}$ & 0.0261 & 0.18 \\
\hline $\mathrm{C}_{20: 0}$ & 0.37 & 0.38 & 0.38 & 0.49 & 0.3940 & 0.03 \\
\hline$C_{20: 1}$ & 0.13 & 0.20 & 0.28 & 0.13 & 0.6015 & 0.04 \\
\hline $\mathrm{C}_{303}$ & 0.50 & 0.29 & 0.43 & 0.32 & 0.1642 & 0.04 \\
\hline $\mathrm{C}_{20: 4}$ & 2.83 & 2.18 & 1.78 & 2.23 & 0.1512 & 0.16 \\
\hline $\mathrm{Cl} A$ & $0.19^{b}$ & $0.35^{a b}$ & $0.49^{3}$ & $0.29^{\mathrm{ab}}$ & 0.0125 & 0.04 \\
\hline others & 0.95 & 0.60 & 0.48 & 1.90 & 0.3096 & 0.29 \\
\hline Sum of unsaturated acids & 52.44 & 54.28 & 56.33 & 53.09 & 0.0606 & 0.57 \\
\hline$n-6: n-3$ ratio & $14.33^{4}: 1$ & $6.75^{\mathrm{H}}: 1$ & $5.63^{\mathrm{R}}: 1$ & $14.08^{\star}: 1$ & 0.0016 & 1.33 \\
\hline
\end{tabular}

A, $B$ P $<0.01 ;$ a.b $\mathbf{P}<0.05$

TABLE 3

Chemical composition of liver and content of some fatty acids in fat, $\%$ of total FA

\begin{tabular}{|c|c|c|c|c|c|c|}
\hline \multirow{2}{*}{ Item } & \multicolumn{4}{|c|}{ Group } & \multirow{2}{*}{$\mathbf{P}$} & \multirow{2}{*}{ SE } \\
\hline & $\mathrm{I}_{\mathrm{K}}$ & $\mathrm{II}_{O P}$ & III $_{O M}$ & $I V_{1.1}$ & & \\
\hline Dry matter, $\%$ & 29.02 & 30.06 & 31.47 & 30.45 & 0.1280 & 0.37 \\
\hline Crude protein, $\%$ & 20.18 & 20.66 & 21.32 & 21.25 & 0.2667 & 0.23 \\
\hline Ether extract, $\%$ & 2.56 & 3.22 & 3.75 & 3.14 & 0.5189 & 0.27 \\
\hline Total cholesterol, $\mathrm{mg} \%$ & 378.43 & 412.55 & 428.45 & 433.03 & 0.6624 & 16.01 \\
\hline \multicolumn{7}{|l|}{ Fatty acids } \\
\hline C.18:0 & 28.81 & 25.30 & 25.02 & 26.76 & 0.0545 & 0.57 \\
\hline C.18:1 & $27.62^{\mathrm{h}}$ & $30.35^{\mathrm{a}}$ & $30.15^{\mathrm{a}}$ & $28.55^{\mathrm{b}}$ & 0.0393 & 0.42 \\
\hline C.18:2 & $10.30^{\mathrm{b}}$ & $11.07^{\mathrm{ab}}$ & $11.41^{\text {sh }}$ & $11.96^{\mathrm{a}}$ & 0.0139 & 0.21 \\
\hline C. $18: 3$ & 2.47 & 4.24 & 3.92 & 2.79 & 0.2177 & 0.35 \\
\hline CLA & $0.16^{13}$ & $0.35^{\wedge}$ & $0.35^{\mathrm{A}}$ & $0.33^{\prime}$ & 0.0003 & 0.02 \\
\hline
\end{tabular}




\section{DISCUSSION}

The supplementation of concentrate with linseed $(10 \%)$ caused not only an increase in the contents of fat and energy in diets but also changed their fatty acid profile. Linseed did not disturb rumen function (Micek et al., 2004). Probably for this reason no significant effect of linseed was found on the performance of animals and chemical composition of their products. On the other hand, the increased content of polyunsaturated fatty acids, including CLA in meat and liver, increased their health value because of their hypocholesterolemic and anticarcinogenic properties (Bartnikowska and Kulasek, 1994). Supplementation also results in a more desirable ratio of n-6 to n-3 unsaturated fatty acids (groups $\mathrm{II}_{\mathrm{OP}}$ and $\mathrm{III}_{\mathrm{OM}}$ ).

\section{CONCLUSIONS}

The $10 \%$ supplement of linseed to concentrate mixtures for fattened lambs had no negative effect on the performance of the animals and had no effect on the chemical composition of their meat and liver.

\section{REFERENCES}

AOAC, 1995. Oflicial Methods of Analysis, Association of Official Chemists. 16th I:dition. Arlington, VA

Bartnikowska E.. Kulasek G., 1994. Importance of unsaturated fatty acids in human and animal nutrition (part II). Deficiencies and dietetic treatment of deficiencies. Mag. wet. 4. 34-38

Borowiec F., 7ając T.. Kowalski 7.M.. Micek P., Marciński M., 2001. Comparison of nutritive value of new commercial linseed oily cultivars for ruminants. J. Anim. Feed Sci. 10, 301-308

Jenkins T.C., 1993. Symposium: Advances in ruminant lipid metabolism. Lipid metabolism in the rumen. J. Dairy Sci. 76, 3851-3863

Micek P., Borowiec F., Marciński M., 2004. Linseed-based diets for sheep. 1. Nutrient digestibility, $\mathrm{N}$ retention and rumen fermentation. J, Anim. Feed Sci. 13, Suppl, 2, 15-18

SAS, 1995. SAS/STAT User Guide V. 6. Volume 1,2. SAS Inst. Inc. Cary, NC

\section{STRESZCZENIE}

Wplyw nasion Inu w dawkach pokarmowych dla owiec. 2. Wyniki produkcyjne oraz skład chemiczny mięsa i wątroby

Badano wpływ nasion Inu odmian o tradycyjnym (Opal, Omega) lub zmodyfikowanym profilu kwasów thuszczowych (Linola) na efekty produkcyjne oraz skład chemiczny mięsa i wątroby tuczonych jagniąt. Zwierzęta żywiono sianem łąkowym oraz micszanką treściwą bez dodatku nasion lnu (grupa kontrolna) lub \% 10\% udzialem nasion lnu róznych odmian (grupy doświadczalne). Nie stwierdzono statystycznie istotnego wpływu skarmiania mieszanek $z$ dodatkiem Inu na przyrosty masy ciała jagnią, wykorzystanic paszy, wydajność rzeźną i skład chemiczny produktów. Stwierdzono natomiast statystyconie istotne zmiany w składzie kwasów thuszczowych mięsa i wątroby, zwłaszcza zwiększenie udziału kwasów $\mathrm{C}_{18: 1}, \mathrm{C}_{18: 2,2} \mathrm{C}_{18: 3}$ i CLA. 